\title{
Key Success Internal and External Factors to Support the Competitiveness of Village Owned Entreprise
}

\author{
Bambang Jatmiko ${ }^{1, *}$ Suryo Pratolo ${ }^{1, *}$ Mibahul Anwar ${ }^{1, *}$ Kholifah Fil Ardhi ${ }^{1}$ \\ ${ }^{1}$ Universitas Muhammadiyah Yogyakarta, Indonesia \\ "Corresponding author.Email: bambang_jatmiko65@yahoo.com
}

\begin{abstract}
The purpose of this study is to test and empirically prove the internal and external factors to support the competitiveness of BUMDes in the Special Region of Yogyakarta. The method uses survey with questionnaire data. The research objects in this study were all BUMDes in 4 districts of the Special Region of Yogyakarta with a total of 178 BUMDes. The results of his research show that: 1) Internal factors with indicators of capital, human resources, law and accountability do not affect the competitiveness of BUMDes; 2). External factors with indicators of Business Climate, Infrastructure and access have no effect on BUMDes Competitiveness. Research outputs in the form of: Call for Paper in the form of Proceedings; International Reputable International Journal, Vidio, Local / National Newspaper News, Reference Books.
\end{abstract}

Keywords: Internal Factor, External Factor, Competitiveness, and Village Owned Enterprise (BUMDes).

\section{INTRODUCTION}

After the enactment of Law no. 6 of 2014 concerning Villages has an impact on the village economy. The village, which has been considered an underdeveloped area, has the opportunity to change the face of the village to be more prosperous and independent. BUMDesa is a business entity that is wholly or most of the capital owned by the village through direct participation from separated village assets in order to manage assets, services and other businesses for the maximum welfare of the village community.

The establishment of BUMDes has a variety of purposes as stated in Article 3 Permendesa No. 4 of 2015, namely: a) improving the village economy; b) optimizing village assets in order to benefit village welfare; c) increasing community efforts in managing the economic potential of the village; d) developing plans for intervillage business cooperation and / or with third parties; e) create market opportunities and networks that support citizens' public service needs; f) creating employment opportunities; g) improving community welfare through improved public services, growth and even distribution of the village economy; and $\mathrm{h}$ ) increase village community income and village income (PADes). The existence of BUMdes with this objective is hoped that the village will become more prosperous and independent. Efforts to achieve an independent and prosperous village require Good Practice management of BUMDes' performance.
Good BUMDes management cannot be separated from the role of the community, government, and BUMDes managers themselves. Ach. Qosjim in his research entitled Analysis of BUMDes Performance in Lumajang Regency states that BUMDes performance is influenced by several factors, namely: a) Institutional governance is a key determinant of the business success of each type of BUMDes; b) The sustainability of BUMDes is strongly influenced by the scale and reach of the business; and c) BUMDes that grow from social solidarity and local wisdom are much stronger and more sustainable than BUMDes that were born due to government intervention from above [1]. The performance of BUMDes also consists of various aspects, as mentioned by Sari and Sri who examined the Performance Analysis of Village-Owned Enterprises (Bumdes) in Pohuwato Village, Pohuwato Regency, mentioning aspects in BUMDes performance [2]. Jaryono and Tohir in their research entitled Analysis of the Performance of BUMDes "Prosperous Business Partners" in Its Effect on Village Original Income (Pades) in Susukan Village, Sumbang District, Banyumas Regency, that the development of a business unit that continues to run, provides positive values for Susukan Village itself. , namely the additional contribution of revenue to the Village Original Income (PADes) of Susukan Village [3].

As for the problem in research on BUMDes, some areas of the Special Region of Yogyakarta (DIY) are in rural areas [4]. The Human Development Index (HDI) in DIY is relatively low. There are 3 districts that have a low HDI or below 80, namely Bantul District 
(75.58), Kulon Progo Regency (75.33), and Gunungkidul Regency (71.11). In these three districts, the villages are currently relied on as a support for community life, especially in the field of food production. In addition, the problem of BUMDes in the Special Region of Yogyakarta, Kulon Progo Regency there are 30 BUMDes Good Practice, 20\% good performance and $80 \%$ sufficient and heading for less good Bantul Regency has 38 BUMDes, $7.9 \%$ of BUMDes are advanced and independent and the remaining $92.1 \%$ is sufficient and even less good. From the 144 villages there are only 72 BUMDes, meaning that $50 \%$ of the villages have developed BUMDes as a source of village income. The problem is in Gunungkidul Regency, the village government and the community are still unable to explore the potential of the village. From the 86 villages, there are 38 villages that already have BUMDes, the problem is there are still many obstacles and the community thinks that business management must be managed by village officials. Based on the above problems, the purpose of this study is to test and empirically prove the internal and external factors to support the competitiveness of BUMDes in the Special Region of Yogyakarta.

\section{LITERATURE REVIEW}

Stewardship theory has its roots in psychology and sociology and was designed for researchers to examine situations in which executives as stewards are motivated to act in the best interests of their principals [5]. In stewardship theory, the model of man is based on a steward whose behavior is ordered such that proorganizational, collectivistic behaviors have higher utility than individualistic, self-serving behaviors [6]. Stewardship theorists argue that the performance of a steward is affected by whether the structural situation in which he or she is located facilitates effective action.

Glinkowska and Boguslaw Stewardship theory is focusing on managerial behavior. It states that the key motivating factor for managers is getting satisfaction from a job well done [7]. Thus, their behavior is proorganizational and in line with organization's interests. There is no conflict between managers and shareholders.

Village-owned enterprises are village business institutions managed by the community and village government in an effort to strengthen the village economy and are formed based on the needs and potential of the village. BUMDes according to Law number 32 of 2004 concerning Regional Government was established, among other things, in the context of increasing Village Original Income (PADesa). The four main objectives of establishing BUMDes are: a. Improve the village economy; $b$. Increase village original income; c. Improve the processing of village potential according to community needs; d. Become the backbone of rural economic growth and equity.
To support this research, the researcher refers to several research results that will be used as consideration and to establish the research hypothesis. Research conducted by Jonnius with the title Analysis of the Performance of BUMDes Employees in Kampar Regency, the results are in general the level of performance, potential competence, reality competence and motivation of BUMDes employees in Kampar Regency are high category [8]. Nugroho in his research Evaluation of the Implementation and Impact of the Village-Owned Enterprise Program (BUMDES) on the Welfare of Poor Household Communities (RTM) in Babadan Village, Karangrejo District, Tulungagung Regency (May 2014-April 2015 Period), Implementation of the Bumdes program in Babadan Village District Karangrejo, Tulungagung Regency is quite good, as evidenced by the results of interviews with village communities, especially the poor family category who are quite satisfied with the implementation of the Bumdes program during this year [9]. Hartini et al's research entitled Health Analysis of Financial Performance at BUMDes Sumber Makmur that based on the results of the calculation of the net value of each ratio [10]. Afrijal and Ramadhani in their research Comparative Analysis of the Financial Performance of Village-Owned Enterprises (Bumdes) in Rokan Hulu Regency, the result is that the average current ratio of BUMDes in Rokan Hulu Regency is $277 \%$ and is in very good condition because the value is greater than $200 \%$ [11]. The hypothesis is as follows: 1) If internal factors increase, then the competitiveness of BUMDes will increase: Hypothesis 1 (H1); 2) If external factors increase, then the competitiveness of BUMDes will increase: Hypothesis $2(\mathrm{H} 2)$.

\section{METHODOLOGY}

The method uses a survey with questionnaire data, research is a scientific way to obtain data with specific purposes and uses. The subjects of this research are internal factors, external factors, and the competitiveness of BUMDes throughout the Special Region of Yogyakarta. The research objects in this study were all BUMDes in 4 districts of the Special Region of Yogyakarta with the following details: 1) Kulon Progo Regency, there are 30 BUMDes; 2) Bantul Regency has 38 BUMDes; 3) Gunungkidul Regency has 72 BUMDes; 4) Sleman Regency there are 38 BUMDes. The population in this study were all BUMDes in the Special Region of Yogyakarta with a total of 178 BUMDes. The sampling technique uses the formula Slovin $\mathrm{n}=\frac{N}{1+N \alpha^{2}}$. $178 / 1+178(0.05)^{2}=123$ (number of samples selected).
Description:
$\mathrm{N}$ : Population
n : Sample
$\alpha^{2} \quad$ : error 
The analytical tools used are correlation and regression. Multiple regression analysis aims to examine the effect of one dependent variable on several independent variables. This analysis was carried out by including two independent variables and one dependent variable, consisting of $\mathrm{X} 1=$ internal factors, $\mathrm{X} 2=$ external factors, and $\mathrm{Y}=$ competitiveness. In general, the multiple linear regression formula for samples can be written as follows:

$$
\begin{aligned}
& \mathrm{Y}=\alpha+\beta_{1} \mathrm{X}_{1}+\beta_{2} \mathrm{X}_{2}+\mathrm{e} \\
& \text { Description: } \\
& \mathrm{Y} \quad: \text { Competitiveness } \\
& \alpha \quad: \text { Constanta } \\
& \mathrm{X} 1 \quad \text { : Internal faktor } \\
& \mathrm{X} 2 \quad \text { : External faktor } \\
& \mathrm{e} \quad \text { : Standart error }
\end{aligned}
$$

\section{FINDING AND DISCUSSIONS}

In this discussion, the researcher emphasizes internal and external factors. The internal factors measured include budget, human resources, services, and accountability, while external factors, the measured aspects include: government, natural resources, third parties and public participation.

In this quantitative analysis the researcher uses the Analysis Of Moment Structure (AMOS) analysis tool, a computer program that can be used to create structural equation models (SEM), in addition to several other programs, such as LISREL. In this study the population is all BUMDes workers in the Yogyakarta area (Bantul, Sleman, Kulon Progo, and Gunungkidul Regencies) with a total of 134 BUMDes as research objects, of which all are used to be analyzed using AMOS with the following variable details. For internal factor variables, indicators measured by budget, human resources, service, and accountability. As for the external factor variables measured by the government, natural resources, third parties, and community participation.

In operating AMOS, the first step taken is testing the validity of the instrument. But the results of this data processing show that the data is invalid, and the invalid data must be issued for further testing, because in this data there are many invalid instruments, so the researcher immediately tries to test the effect with existing data.

The results of the discussion on this variable indicate that internal factors on competitiveness show that it is said to be influential if it has a $\mathrm{P}$ value $<0.05$. While these results indicate the $\mathrm{P}$ value of each sub variable (Budget, Human Resources, Services and accountability)> 0.05 which means it is not significant. For external factors, the researcher also analyzed with AMOS, the variables analyzed were external factors with indicators: government, natural resources, third parties, and community participation in competitiveness (differentiation strategy, low cost strategy, and focus strategy).

Tabel 1. Regression Weights: (Group number 1 - Default model)

\begin{tabular}{|lll|llllll|}
\hline & & & Estimate & S.E. & C.R. & P & Label \\
\hline Daya_saing & $<---$ & Anggaran &, 497 &, 407 & 1,220 &, 222 & par_37 \\
Daya_saing & $<---$ & SDM &,- 133 &, 192 &,- 694 &, 488 & par_38 \\
Daya_saing & $<---$ & Pelayanan &, 000 &, 001 &,- 172 &, 863 & par_39 \\
Daya_saing & $<---$ & Akuntabilitas &,- 381 &, 484 &,- 787 &, 431 & par_40 \\
\hline
\end{tabular}

Source: Processed by Researcher

Table 2. Regression Weights: (Group number 1 - Default model)

\begin{tabular}{|lll|llllll|}
\hline & & & Estimate & S.E. & C.R. & P & Label \\
\hline Daya_saing & $<---$ & Pemerintah &, 679 & 1,162 &, 585 &, 559 & par_37 \\
Daya_saing & $<---$ & SDA &, 180 &, 130 & 1,386 &, 166 & par_38 \\
Daya_saing & $<---$ & Pihak_ketiga & $-1,516$ & 1,144 & $-1,325$ &, 185 & par_39 \\
Daya_saing & $<---$ & Peran_masyarakat &,- 002 &, 008 &,- 255 &, 799 & par_40 \\
\hline
\end{tabular}

Source: Processed by Researcher

A variable can be said to be influential if it has a $P$ value $<0.05$. Meanwhile, the results show that the $P$ value of each sub variable (Government, Natural Resources, Third Parties and the Role of the Community) is $>0.05$ which means it is not significant. 


\section{CONCLUSION}

Internal factors of BUMDes (budget, human resources, services, and accountability) do not affect the competitiveness of BUMDes in the Special Region of Yogyakarta (BUMDes Bantul, Sleman, Kulon Progo, and Gunungkidul Regencies). External factors from BUMDes (government, SDA, third parties, and community participation) do not affect the competitiveness of BUMDes in the Special Region of Yogyakarta (BUMDes Bantul, Sleman, Kulon Progo, and Gunungkidul Regencies).

Based on the results of the above research, the researcher can provide suggestions. For future researchers, it is advisable to group BUMDes that have almost the same type of BUMDes product to be the object of research. Future researchers should group BUMDes according to the amount of capital so that they will get the same decision. Future researchers should focus on BUMDes whose villages have tourist objects as one of the BUMDes products because tourism is the biggest contributor to the village's original income.

\section{REFERENCES}

[1] Ach. Qosjim. 2017. Analisis Kinerja BUMDes di Kabupaten Lumajang. Jurnal Ekuilibrium Vol. 2 (1) : 10-17.

[2] Afrijal dan Ramadhani. 2016. Analisis Perbandingan Kinerja Keuangan Badan Usaha Milik Desa (Bumdes) Di Kabupaten Rokan Hulu. Jurnal Ilmiah Cano Ekonomos Vol. 5(1): 1-10. https://media.neliti.com/media/publications/58648ID-analisis-perbandingan-kinerja-keuangan-b.pdf. Dikases 14 Juli 2020.

[3] Aiginger, K. 2006. Competitiveness: from a Dangerous Obsession to A Welfare Creating Ability with Positive Externalities. Journal of Industry, Competition and Trade, Vol. 6 (2): 161-177.

[4] Anas, M. Yusuf Azwar. 2019. Mengapa Sociopreneur Bukan Social Entrepreneur?. Jurnal Dialektika Vol. 4 (2): 67-73.

[5] Beata Glinkowska dan Bogusław Kaczmarek. 2015. Classical and Modern Concepts of Corporate Governance (Stewardship Theory and Agency Theory). Management Vol 19 (2): 84-92.

[6] Bullen, C. V. \& Rockart, J. F. 1981. A primer on critical success factors. Cambridge, MA: Center for Information Systems Research, MIT.

[7] Chikán, A. 2008. National and Firm Competitiveness: A General Research Model. Competitiveness Review: An International Business Journal, Vol. 18, Nos. 1/2, pp.20-28.

[8] Daniel, D.R. (1961). Management Information Crisis. Harvard Business Review : 111-116.
[9] Donaldson, Lex, and James H. Davis. 1991. Stewardship Theory or Agency Theory: CEO Governance and Shareholder Returns. Australian Journal of Management Vol. 16 (1): 49-65. http://citeseerx.ist.psu.edu/viewdoc/download?doi=1 0.1.1.335.9363\&rep=rep1\&type=pdf. Diakses 23 Juli 2020.

[10] Eliyatiningsih, Luri A, S., \& Etikasari, B. 2017. Pembinaan Sociopreneur sebagai Upaya Meningkatkan Kreativitas dan Kemandirian Anak Yatim di Yayasan Raudlatul Akbar Kecamatan Kaliwates Kabupaten Jember. Seminar Nasional Hasil Pengabdian kepada Masyarakat 2017, $73-77$.

[11] Fagerberg, J.1988. International Competitiveness. The Economic Journal, Vol. 98, No. (391) :355-374.

[12] Ferguson, C. R. \& Dickinson, R. (1982). Critical Success Factors for Directors in The Eighties. Business Horizons: 14-20.

[13] Grunert, Klaus G., dan Charlotte Ellegaard. 1992. The Concept of Key Success Factors: Theory and Method. MAPP Working Paper no. 4. https://pure.au.dk/portal/files/32299581/wp04.pdf. Diakses 15 Juli 2020.

[14] Hartini, Makmur, dan Asrori. 2020. Analisis Kesehatan Kinerja Keuangan pada BUMDes Sumber Makmur. https://media.neliti.com/media/publications/110598ID-analisis-kesehatan-kinerja-keuangan-bumd.pdf. Diakses 14 Juli 2020.

[15] Hofer, C. W. \& Schendel, D. (1978). Strategy formulation: Analytical concepts. St. Paul, MI: West Publishing.

[16] James H. Davis, F. David Schoorman and Lex Donaldson. 1997. Toward a Stewardship Theory of Management. The Academy of Management Review Vol. $\quad 22 \quad$ (1) $\quad: \quad 20$ 47.https://www.jstor.org/stable/pdf/259223.pdf. Diakses 23 Juli 2020

[17] Jaryono, dan Tohir. 2019. Analisis Kinerja BUMDes "Mitra Usaha Makmur" dalam Pengaruhnya terhadap Pendapatan Asli Desa (Pades) Desa Susukan Kecamatan Sumbang Kabupaten Banyumas. Sustinable Competitive Advantage-9 (SCA-9) FEB UNSOED: 23-30.

[18] Jonnius. 2014. Analisis Kinerja Karyawan Bumdes Di Kabupaten Kampar. Kutubkhanah: Jurnal Penelitian sosial keagamaan, Vol.17 (1) : 84-103.

[19] Ketelhohn, Werner. 1998. What is Key Success Factor?. European Management Journal Vol. 16 (3) : 335-340.

https://www.sciencedirect.com/science/article/abs/pii /S0263237398000103. Diakses 15 Juli 2020. 
[20] Krugman, P. 1996. Making sense of the competitiveness debate. Oxford Review of Economic Policy, Vol. 12 (3) :17-25.

[21] Mahmudi. 2011. Akuntansi Sektor Publik. Yogyakarta : UII Press.

[22] Mardiasmo. 2009. Akuntansi Sektor Publik. Yogyakarta: CV. Andi Offset.

[23] Mathi, Kavindra. 2004. Key Success factors For Knowledge Management. Germany : Metzeler GmbH, Lindau. http://hosteddocs.ittoolbox.com/km21105.pdf. Diakses 15 Juli 2020.

[24] Nugroho, Dendhi Agung. 2015. Evaluasi Penerapan dan Dampak Program Badan Usaha Milik Desa (BUMDES) Terhadap Kesejahteraan Masyarakat Rumah Tangga Miskin (RTM) di Desa Babadan Kecamatan Karangrejo Kabupaten Tulungagung (Periode Mei 2014-April 2015). JESP Vol.7 (2) : 7984.

[25] Ohmae, K. (1982). The Mind of the Strategist. New York: McGraw-Hill Book Company.

[26] Porter, M.E. 1990. Competitive Advantage of Nations, Free Press. New York.

[27] Powell, T.C. (2001) 'Competitive Advantage: Logical and Philosophical Considerations', Strategic Management Journal, Vol. 22 (12) : 875-888.

[28] Prabowo, T.H.E. 2014. Developing BUMDes (Village-owned Enterprise) for Suitainable Poverty Alleviation Model Village Community Study in Bleberan-Gunungkidul-Indonesia. World Applied Sciences Journal 30 (Innovation Challenges in Multidiciplinary Research \& Practice) : 19-26.

[29] Praszkier, R., Nowak, A., \& Zablocka-Bursa, A. (2009). Social Capital Built by Social Entrepreneurs and The Specipc Personality Traits that Facilitate The Process. Psychologia Spo eczna, 42-51.

[30] Purwiyanti, Dwi. 2017. ANALISIS KINERJA BERBASIS KONSEP VALUE FOR MONEY PADA KEGIATAN FISIK PEKERJAAN IRIGASI DONGGALA KODI (Study di Dinas Pekerjaan Umum Kota Palu). e Jurnal Katalogis, Vol. 5 (3) : 190-200.

https://media.neliti.com/media/publications/190733ID-analisis-kinerja-berbasis-konsep-value-f.pdf. Dikases 16 Juli 2020.

[31] Rockart, J. F. 1979. Chief Executives Define Their Own Data Needs. Harvard Business Review.

[32] Sari, Purnama., dan Sri wahyuni Ummur. 2019. Analisis Kinerja Badan Usaha Milik Desa (Bumdes) Didesa Pohuwato Kabupaten Pohuwato. Accountia Jounal (accounting, Trusted, Inspiring, Authentic Journal Vol.3, No. 2, Oktober 2019 : 425-442. http://jurnal.stiemtanjungredeb.ac.id/index.php/accou ntia/article/view/385/238. Diakses 14 Juli 2020.

[33] Silvia, Marginean. (2006). Competitiveness: From Microeconomic Foundations to National Determinants. Studies in Business and Economics. 1. 29-35.

[34] Ulum, Ihyaul. 2004.Akuntansi Sektor Publik (Suatu Pengantar). Malang: UMM Press. 